\title{
Fluorimetric Immunoassay for Multianalysis of Aflatoxins
}

\author{
Lizy Kanungo and Sunil Bhand \\ Biosensor Lab., Department of Chemistry, BITS, Pilani-K. K. Birla Goa Campus, Goa 403726, India \\ Correspondence should be addressed to Sunil Bhand; sunil17_bhand@yahoo.com \\ Received 16 April 2013; Revised 27 June 2013; Accepted 28 June 2013 \\ Academic Editor: Lingzhi Liu
}

Copyright (C) 2013 L. Kanungo and S. Bhand. This is an open access article distributed under the Creative Commons Attribution License, which permits unrestricted use, distribution, and reproduction in any medium, provided the original work is properly cited.

A sensitive fluorimetric ELISA was developed for the analysis of aflatoxins. The assay was performed in a 384 microwell plate, wherein high specificity monoclonal antibody against AFM1 (mAb-AFM1) was used as capture antibody and FITC conjugated secondary antibody was used for detection and quantification of the analyte. The linear range of the immunoassay was found to be $6.25-50 \mathrm{pg} / \mathrm{mL}$. AFM1 as low as $1 \mathrm{pg} / \mathrm{mL}$ was detected by this method with assay volume $40 \mu \mathrm{L}$. The multi-analysis of different aflatoxins was also investigated in the microwell plate, based on the cross-reactivity (CR) approach. Real milk samples were tested along with certified reference material by standard addition method and recovery analysis was done. The mAb-AFM1 showed 23.2\% CR with AFB1, 50\% CR with respect to AFM2, and least CR towards AFG1 $(<1 \%)$. Furthermore, mixture analysis of AFM2 and AFB1 was carried out at specific concentrations of AFM1. The advantages of this developed immunoassay are high sensitivity, high throughput, multianalyte detection, versatility, and ease of handling.

\section{Introduction}

Aflatoxins are highly toxic, mutagenic, carcinogenic, and teratogenic compounds contaminating a wide range of food com-modities $[1,2]$. The major naturally occurring aflatoxins, namely, AFB1, AFB2, AFG1, and AFG2, constitute a class of structurally related toxic fungal metabolites. They are extremely potent carcinogens and can have significant economic impacts, making them important targets for detection and quantification [3]. Commodities frequently contaminated by aflatoxins include cereals, nuts, dried fruits, spices, and pulses $[4,5]$. When animals consume AFB1 contaminated foodstuffs, the toxin is metabolized in the liver and excreted as AFM1 via milk and urination [1]. Humans are exposed to the deleterious effects of aflatoxins either directly by eating contaminated grains or indirectly via animal products [6]. Evidence of hazardous human exposure to aflatoxins through various foods including dairy products has been shown by several investigators $[1-3,7]$.

Many analytical methods have been developed for estimation of aflatoxins in agricultural commodities. Among them optical and electrochemical transducers are most widely used for detection of aflatoxins. The optical detection method is regarded as one of the sensitive techniques for aflatoxin analysis. The optical signal is not influenced by electrical, magnetic, or ionic fields. Table 1 gives an account of some of the reported biosensors for analysis of AFM1 and AFB1.

It is evident that the need for a highly selective multianalyte detection system is acute. Simultaneous analysis of aflatoxins is essential to minimize the consumption of contaminated food and feed and import surveillance programs and controlling quality of products $[5,8,9]$. There is a need for development of single platform for simultaneous analysis of these toxins. Few attempts have been made towards development of immunosensors capable of both discriminative detection and class-selective multianalyte analysis. In one such approach, multianalysis of aflatoxins was investigated by development of an immunoaffinity column. This was done by covalently coupling monoclonal antibody 1C11 against aflatoxins to amino-silica gel microparticles and then packing these into a cartridge. This immunoaffinity column was subsequently used for selective extraction of aflatoxins in agriproducts [10]. In a recent article, novel peptide mimics of aflatoxin (mimotopes) have been used for analysis of aflatoxins [11]. In this work, 5 such mimotopes were obtained and used 
TABLE 1: Reported biosensing techniques for analysis of AFM1 and AFB1.

\begin{tabular}{|c|c|c|c|}
\hline Biosensing technique & Analyte & $\begin{array}{l}\text { Detection } \\
\text { limit }\end{array}$ & Reference \\
\hline $\begin{array}{l}\text { Surface plasmon } \\
\text { resonance (SPR) } \\
\text { immunoassay }\end{array}$ & AFB1 & $3 \mathrm{ng} / \mathrm{mL}$ & {$[13]$} \\
\hline $\begin{array}{l}\text { Optical } \\
\text { (chemiluminescent) } \\
\text { enzyme immunoassay }\end{array}$ & AFB1 & $0.01 \mathrm{ng} / \mathrm{g}$ & {$[14]$} \\
\hline Long range SPR & AFM1 & $0.6 \mathrm{pg} / \mathrm{mL}$ & {$[15]$} \\
\hline SPR & AFB1 & $0.2 \mathrm{ng} / \mathrm{mL}$ & {$[8]$} \\
\hline Impedance & AFM1 & $15 \mathrm{ng} / \mathrm{L}$ & {$[16]$} \\
\hline $\begin{array}{l}\text { Impedance and cyclic } \\
\text { voltammetry }\end{array}$ & AFM1 & $1 \mathrm{ng} / \mathrm{mL}$ & [17] \\
\hline $\begin{array}{l}\text { Bioelectronic } \\
\text { recognition assay }\end{array}$ & AFM1, AFB1 & $5 \mathrm{pg} / \mathrm{mL}$ & {$[18]$} \\
\hline $\begin{array}{l}\text { Linear sweep } \\
\text { voltammetry }\end{array}$ & AFM1 & $0.054 \mathrm{ng} / \mathrm{mL}$ & {$[6]$} \\
\hline $\begin{array}{l}\text { Direct competitive } \\
\text { ELISA (MNPs) }\end{array}$ & AFM1 & $8 \mathrm{ng} / \mathrm{L}$ & {$[19]$} \\
\hline $\begin{array}{l}\text { Indirect competitive } \\
\text { ELISA }\end{array}$ & AFM1 & $5 \mathrm{ng} / \mathrm{L}$ & {$[20]$} \\
\hline $\begin{array}{l}\text { Indirect competitive } \\
\text { ELISA }\end{array}$ & AFM1 & $0.24 \mathrm{ng} / \mathrm{mL}$ & {$[21]$} \\
\hline $\begin{array}{l}\text { Flow-injection } \\
\text { immunoassay }\end{array}$ & AFM1 & $11 \mathrm{pg} / \mathrm{mL}$ & {$[22]$} \\
\hline Competitive ELISA & AFM1 & $28 \mathrm{ng} / \mathrm{kg}$ & {$[23]$} \\
\hline $\begin{array}{l}\text { Indirect competitive } \\
\text { ELISA }\end{array}$ & AFM1 & $0.04 \mathrm{ng} / \mathrm{mL}$ & {$[24]$} \\
\hline Competitive ELISA & AFM1 & $39 \mathrm{ng} / \mathrm{L}$ & {$[25]$} \\
\hline SPR & AFB1, AFG1 & $0.97 \mathrm{~g} / \mathrm{kg}$ & {$[26]$} \\
\hline $\begin{array}{l}\text { Chemiluminescent } \\
\text { ELISA }\end{array}$ & AFM1 & $0.05 \mathrm{pg} / \mathrm{mL}$ & [27] \\
\hline $\begin{array}{l}\text { Electrochemical } \\
\text { impedance spectroscopy }\end{array}$ & AFM1 & $1 \mathrm{pg} / \mathrm{mL}$ & {$[28]$} \\
\hline Fluorometric ELISA & $\begin{array}{l}\text { AFM1, AFM2, } \\
\text { AFB1, AFG1 }\end{array}$ & $1 \mathrm{pg} / \mathrm{mL}$ & This work \\
\hline
\end{tabular}

in an indirect competitive ELISA for analyzing total aflatoxin concentration in peanut and feedstuffs. In another interesting article, multianalysis of different triazine herbicides using CR of antibodies coupled to pattern recognition has been reported [12]. A similar approach could be implemented for multianalysis of different aflatoxins which are structurally similar (Figure 1).

In this work, a simple ELISA was developed using fluorimetric technique. We performed fluorimetric analysis of AFM1 using FITC conjugated secondary $\left(2^{\circ}\right)$ antibody in 384 microwell plate as shown in Figure 2. Multianalysis of different aflatoxins was carried out by CR approach. The microwell plate was coated with anti-AFM1 primary $\left(1^{\circ}\right)$ monoclonal antibody (mAb) which reacted with AFM1 and partly recognized structurally similar aflatoxins such as AFM2, AFB1, and
AFG1. Subsequently we analyzed 2 real milk samples using standard addition method, and recovery rate was studied. The CR was studied and mixture analysis was carried out. The occurrence of cocontaminants was detected by this mixture analysis.

\section{Experimental}

2.1. Chemicals and Instrumentation. AFM1, bovine serum albumin (BSA), Tween 20, and certified reference material (CRM) ERM-BD282 (AFM1 in whole milk powder, $<0.02 \mu \mathrm{g} / \mathrm{kg}$ ) were obtained from Sigma-Aldrich (USA). AFB1, AFG1 were purchased from Acros Organics, USA. AFM2 was purchased from Fermentek, Israel. Acetonitrile (ACN) HPLC grade and sodium chloride $(\mathrm{NaCl})$ were purchased from Merck (Germany). Sodium hypochlorite (4\%) solution was purchased from Fisher Scientific (India). Rat monoclonal [1C6] primary antibody ( $\left.1^{\circ} \mathrm{Ab}\right)$ of AFM1 and FITC conjugated $2^{\circ} \mathrm{Ab}$ were purchased from Abcam (UK). Milk samples were centrifuged by MiniSpin Plus centrifuge purchased from Eppendorf (Germany) and shaking of the samples were done by Spinix shaker, purchased from Tarsons (India). 0.22 micron filter papers (25 mm diameter) obtained from Millipore (USA) were used for filtration of milk samples. White 384 well polystyrene microtiter plates were purchased from Nunc (Denmark). For fluorimetric measurement, VictorX ${ }^{4} 2030$ OptiPlate reader from Perkin Elmer (USA) was used. A glove box, Cole Parmer (USA), was used for the handling of all aflatoxin standard solutions. Water produced in a Milli-Q system (Millipore, Bedford, MA, USA) was used to prepare all the solutions. pH meter from SevenMulti Mettler Toledo, Switzerland, was used to prepare buffers. For sample handling, micropipettes (Eppendorf, Germany) were used. Milk samples were purchased from the local markets of Goa, India. The data processing was done by Origin 6.1 (Microcal, USA).

2.2. Preparation of Buffers. Carbonate buffer $(\mathrm{CB} ; 0.05 \mathrm{M}, \mathrm{pH}$ 9.6), phosphate buffered saline (PBS; 0.01 M, pH 7.4), PBST (PBS with Tween 20), and blocking solution (BSA in PBS) were made by the same protocol as described in our earlier paper [27]. All buffer solutions were stored at $4^{\circ} \mathrm{C}$ when not in use.

2.3. Preparation of Aflatoxin Standard Solutions. All the aflatoxin solutions were prepared in a glove box in a maintained inert $\left(\mathrm{N}_{2}\right)$ atmosphere. AFM1 stock solution was prepared by dissolving the AFM1 powder in $5 \% \mathrm{ACN}(\mathrm{v} / \mathrm{v})$ in $\mathrm{PBS}$ at a concentration of $5 \mu \mathrm{g} / 2 \mathrm{~mL}$ and stored at $2-8^{\circ} \mathrm{C}$. Working standard solutions in the range of $1-500 \mathrm{pg} / \mathrm{mL}$ were prepared by diluting the stock with 5\% ACN. AFM2 standard solutions were also made in the similar way. AFB1 stock solution $1000 \mu \mathrm{g} / \mathrm{mL}$ was prepared by dissolving the crystalline AFB1 in $5 \% \mathrm{ACN}(\mathrm{v} / \mathrm{v})$ in PBS and stored at $4^{\circ} \mathrm{C}$. Working AFB1 standard solutions were prepared in the following concentrations: $1,6.25,12.5,25,50,100,250$, and $500 \mathrm{pg} / \mathrm{mL}$ by diluting the stock with $5 \%$ ACN. AFG1 standard solutions were also 
<smiles>COc1cc2c(c3oc(=O)c4c(c13)CCC4=O)C1C=COC1O2</smiles>

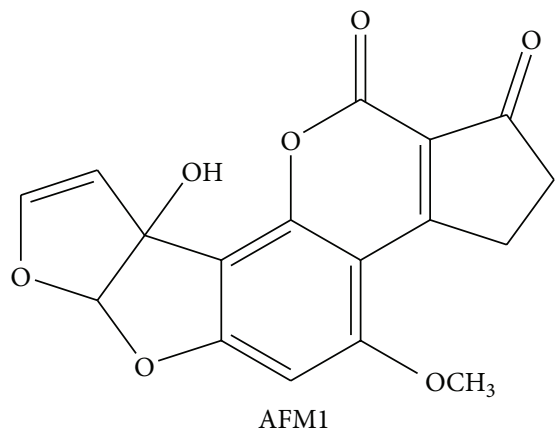<smiles>COc1cc2c(c3oc(=O)c4c(c13)COC4=O)C1C=COC1O2</smiles><smiles>COc1cc2c(c3oc(=O)c4c(c13)CCC4=O)C1(O)CCOC1O2</smiles>

FIGURE 1: Chemical structures of different aflatoxins.

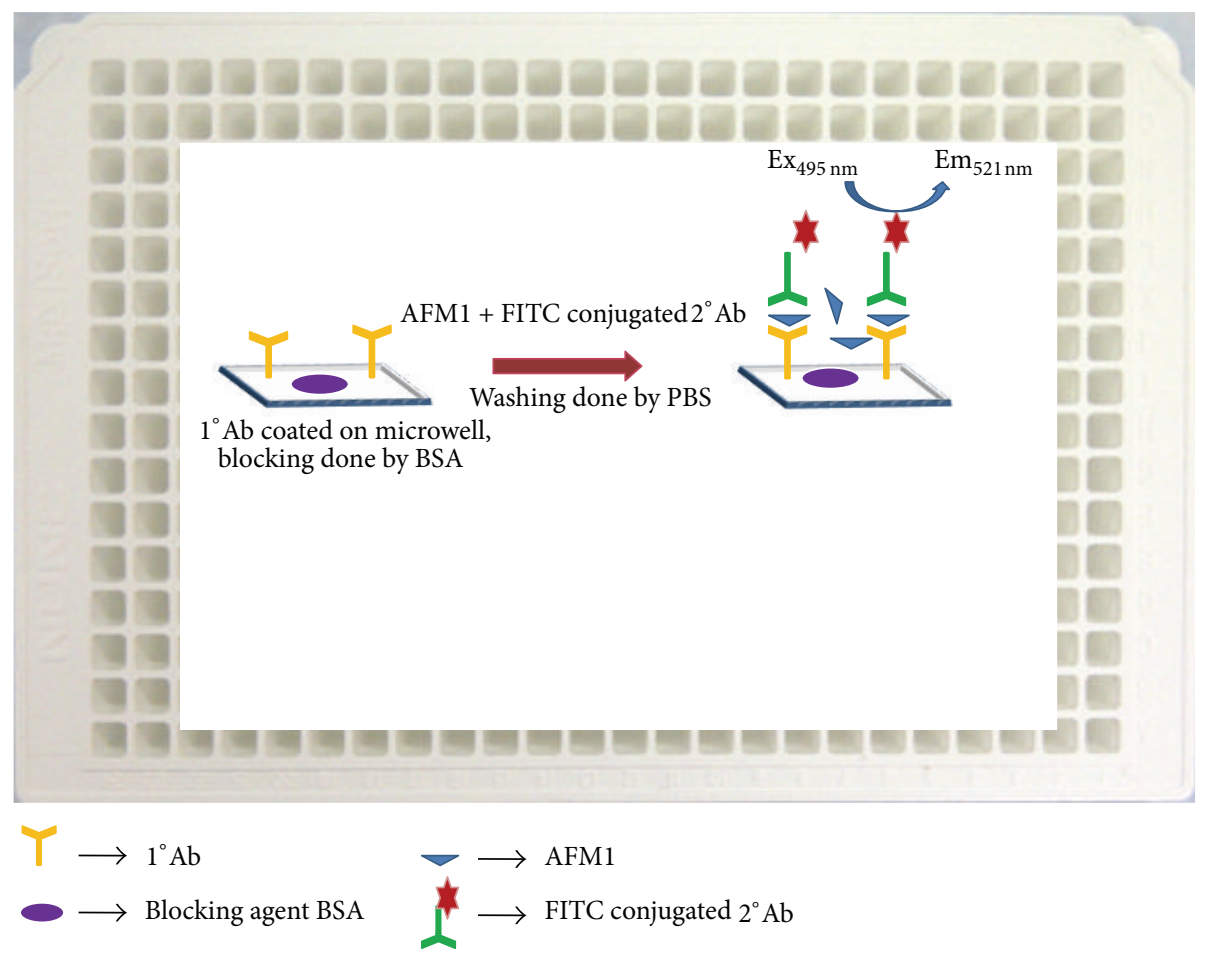

FIGURE 2: Scheme of fluorimetric ELISA designed for analysis of AFM1.

made in the similar manner. (Safety note: aflatoxins are highly carcinogenic and should be handled with extreme care. Aflatoxin contaminated labware should be decontaminated with an aqueous solution of sodium hypochlorite (4\%).)
2.4. Preparation of Aflatoxin Antibody Solutions. The stock solution of rat monoclonal [1C6] $1^{\circ} \mathrm{Ab}, 100 \mu \mathrm{g}(1 \mathrm{mg} / \mathrm{mL})$ was diluted with $50 \mu \mathrm{L}$ of pyrogen free deionized water. It was divided into 2 fractions. The first fraction containing $40 \mu \mathrm{L}$ 


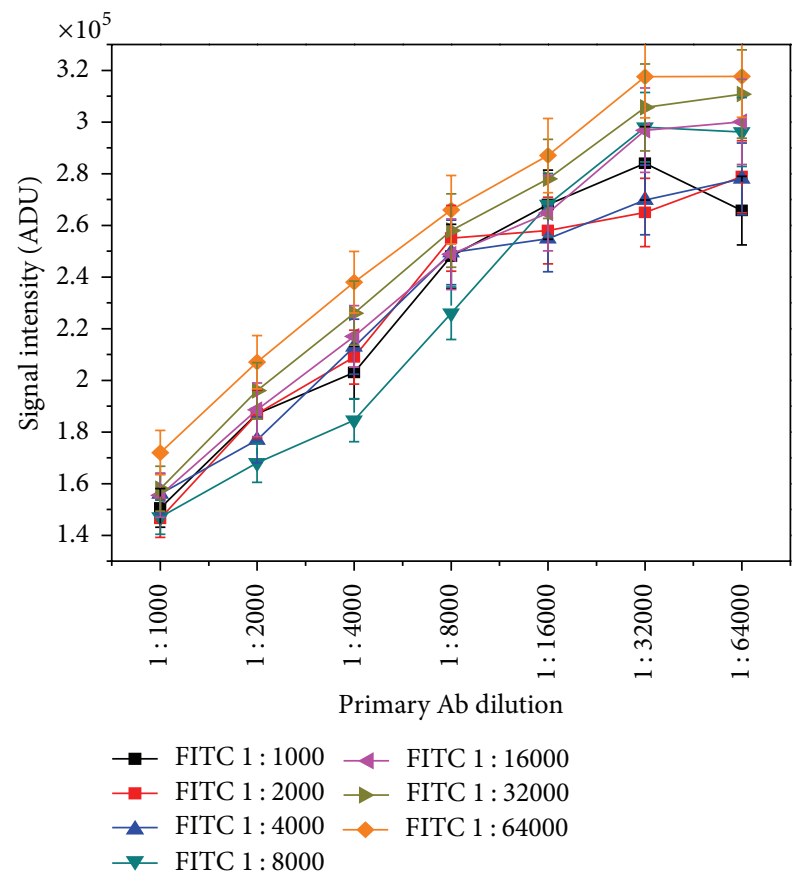

Figure 3: Optimization curve of FITC labeled $2^{\circ} \mathrm{Ab}$ against $1^{\circ} \mathrm{Ab}$.

was stored at $-20^{\circ} \mathrm{C}$. From the second fraction, the working antibody dilutions were prepared by serial dilution in double distilled water as $1: 1000,1: 2000$, and so forth and then added with equal volume of CB (1:1). From the FITC labeled $2^{\circ} \mathrm{Ab}$ stock $1 \mathrm{mg}(2 \mathrm{mg} / \mathrm{mL})$ solution, $100 \mu \mathrm{L}$ was diluted with $500 \mu \mathrm{L}$ of deionized water. It was divided into 2 fractions. The first fraction containing $400 \mu \mathrm{L}$ was stored in $-20^{\circ} \mathrm{C}$. From the second fraction, working $2^{\circ} \mathrm{Ab}$ solution was prepared prior to the experiment by serial dilution in PBS as 1:1000, $1: 2000$, and so forth.

2.5. Milk Sample Pretreatment. CRM-BD282 milk powder comprising zero level AFM1 was reconstituted in the following manner. One g of CRM-BD zero level milk powder was dissolved in $10 \mathrm{~mL}$ of warm PBS. Then it was centrifuged at $6000 \mathrm{rpm}$ for $10 \mathrm{~min}$. The upper fatty layer was completely removed, and middle fat free portion was taken out. The decanted aqueous layer was filtered through a syringe filter using 0.22 micron filter paper. This was further diluted with PBS in 1:1 manner and used for analysis. Packaged milk samples containing 3.5\% fat were collected from the markets of Goa. These packaged milk samples were centrifuged, filtered, and treated in the same manner.

2.6. Fluorimetric Immunoassay Procedure. ELISA was performed in a 384 microwell plate. $1^{\circ} \mathrm{Ab}$ was diluted to $1: 16000$ in $\mathrm{CB}$ and coated as $40 \mu \mathrm{L} /$ well. The plate was covered with parafilm and aluminium foil, kept at $4{ }^{\circ} \mathrm{C}$ for overnight, and washed 3 times by rinsing the wells with $40 \mu \mathrm{L}$ PBS. The remaining protein binding sites in the coated wells were
TABLE 2: Analytical figures of merit of the fluorometric assay developed for analysis of AFM1.

\begin{tabular}{lc}
\hline Analytical parameters & Experimental findings \\
\hline Linear range & $1-50 \mathrm{pg} / \mathrm{mL}^{*}, 6.25-25 \mathrm{pg} / \mathrm{mL}^{\#}$ \\
LOD & $1 \mathrm{pg} / \mathrm{mL}$ \\
$\mathrm{IC}_{50}$ & $100 \mathrm{pg} / \mathrm{mL}^{*}, 86 \mathrm{pg} / \mathrm{mL}^{\#}$ \\
R.S.D. & $1.1 \%^{*}, 0.5 \%^{\#}$ \\
Adj. $R^{2}$ & $0.987^{*}, 0.991^{\#}$ \\
Assay sample volume & $40 \mu \mathrm{L}$ \\
Analysis time & $180 \mathrm{~min}$
\end{tabular}

Sample throughput 128 samples (in triplicate) in $180 \mathrm{~min}$

${ }^{*} \mathrm{PBS} ;{ }^{\#} \mathrm{CRM}-\mathrm{BD} 282$.

blocked by adding $40 \mu \mathrm{L}$ of blocking solution for about $1 \mathrm{~h}$ at room temperature. The wells were washed twice with $40 \mu \mathrm{L}$ PBST. Following this step, AFM1 standard solution in the range $1-500 \mathrm{pg} / \mathrm{mL}$ was mixed up (at equal volume) separately with optimized $2^{\circ} \mathrm{Ab}$ (diluted to 1:64000 in PBS) solution. This antigen-antibody mixture solution was then added as $40 \mu \mathrm{L} /$ well. The plate was incubated for about $2 \mathrm{~h}$ at room temperature. The excess label was removed by washing with PBS. The microplate was then analyzed by Victor $X^{4} 2030$ optiplate reader in fluorescence mode.

\section{Results and Discussion}

3.1. Optimization of Antibody Dilutions. The FITC labeled $2^{\circ} \mathrm{Ab}$ solutions were made by serial dilution from 1:1000 up to $1: 128000$. Figure 3 shows the optimization result obtained for FITC labeled $2^{\circ} \mathrm{Ab}$ with $1^{\circ} \mathrm{Ab}$ in fluorimetric assay. It was observed that FITC labeled antibody at 1:64000 dilution showed best signal $\left(3.2 \times 10^{5}\right)$ count when assayed with $1^{\circ} \mathrm{Ab}$. The excitation time was $0.1 \mathrm{~s}$.

3.2. Optimization of Incubation Time. In order to achieve the optimal binding of analyte, the incubation time varied from $10 \mathrm{~min}$ to $180 \mathrm{~min}$. Figure 4 shows the optimization result of incubation time of AFM1 and FITC labeled $2^{\circ} \mathrm{Ab}$ complex with capture $1^{\circ} \mathrm{mAb}$. It is apparent from the graph that around 100-120 min, the stable signal was obtained. So, the incubation time was chosen at $120 \mathrm{~min}$ in further experimental analysis.

3.3. Calibration of AFM1. Different concentrations of AFM1 were tested both in PBS and in CRM-BD282 zero level AFM1 milk powder. Calibration was studied in the range 1$250 \mathrm{pg} / \mathrm{mL}$ by fluorimetric analysis. Figure 5 shows graph of fluorimetric signals obtained for varying concentrations of AFM1 in PBS and CRM-BD282.

In both cases, decrease in the signal intensity was observed with the increase of [AFM1]. The fluorimetric assay 


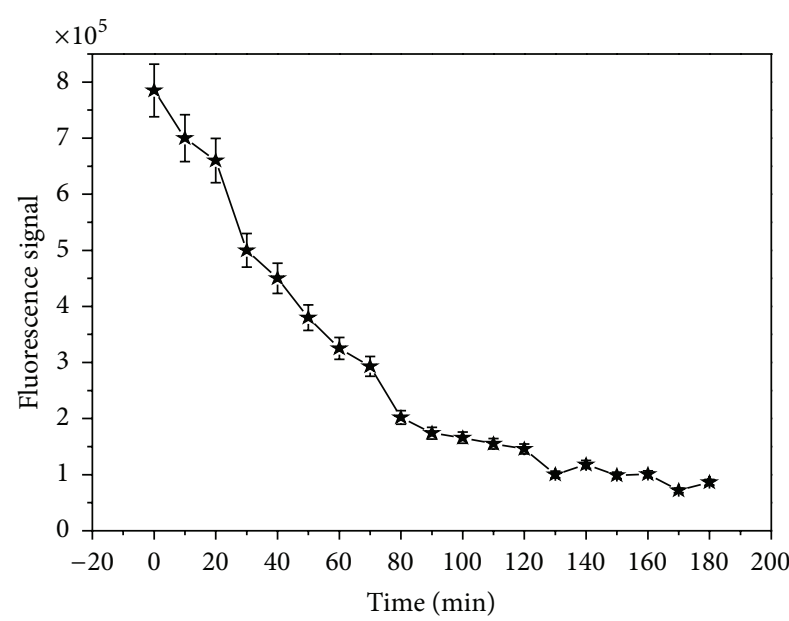

FIgURE 4: Optimization of incubation time for FITC conjugated $2^{\circ} \mathrm{Ab}$. $1^{\circ} \mathrm{Ab}$ dilution, 1:16000; FITC conjugated $2^{\circ} \mathrm{Ab}$ dilution, 1:64000; excitation time, $0.1 \mathrm{~s}$.

could quantify the [AFM1] in an ultrasensitive manner with a lower limit of detection (LOD) at $1 \mathrm{pg} / \mathrm{mL}$. The analytical figures of merit of this AFM1 assay by fluorimetric technique are given in Table 2 .

3.4. Fluorimetric Immunoassay for Multianalysis of Aflatoxins. It is evident that aflatoxins such as AFM1, AFM2, AFB1, and AFG1 have similar structures (Figure 1). Thus the capture antibody that recognizes its specific analyte may also partly recognize the other structural analogues. Bearing this concept in mind, CR studies were carried out for AFM1, AFB1, AFG1, and AFM2 recognition by the $1^{\circ} \mathrm{mAb}$. The anti-AFM1 $\mathrm{mAb}$ was used as capture antibody, and FITC conjugated antibodies were used as $2^{\circ} \mathrm{Ab}$ for recognition of antigen-antibody $(\mathrm{Ag}-\mathrm{Ab})$ complex. The multianalysis of different aflatoxins using the CR with $\mathrm{mAb}$ of AFM1 was studied keeping the competitor concentration constant in all measurements.

The standard solutions of different aflatoxins such as AFM1, AFM2, AFB1, and AFG1 were prepared ranging from 1 to $500 \mathrm{pg} / \mathrm{mL}$. These concentrations were mixed up with FITC labeled $2^{\circ} \mathrm{Ab}$ in equal volume (total $40 \mu \mathrm{L}$ ) and added to four different rows of the microwell plate. After $2 \mathrm{~h}$ of incubation, washing was done to remove any unbound antigen or antibody. Then the plate was analyzed in the multiplate reader.

Figure 6 shows the different aflatoxins specific recognition towards the mAb of AFM1 where concentration of competitor was plotted against $B / B_{0}(\%)$. The CR study result (Figure 6) of fluorimetric assay shows that FITC labeled antiAFM1 antibody showed strong intensity when recognized AFM1-Ab complex. It recognized other aflatoxins differentially. With the increase in [AFM1], the signal intensity decreased due to inhibition.

The CR of $\mathrm{mAb}$ pair was determined in competition with tracer. For standard analyte (for which CR is $100 \%$ ), concentrations that result in $50 \%$ inhibition $\left(\mathrm{IC}_{50}\right)$ of the signal were

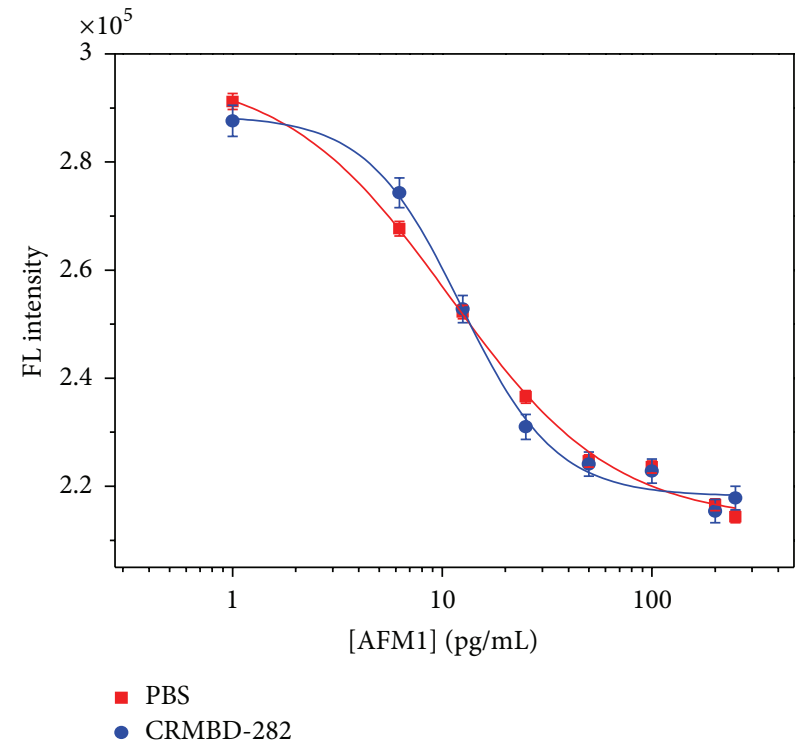

FIgURE 5: Calibration curve of AFM1 obtained using fluorimetric assay in buffer and CRM-BD282. $1^{\circ} \mathrm{mAb}$ dilution, 1:16000; FITC conjugated $2^{\circ} \mathrm{Ab}$ dilution, 1:64000; incubation time, $2 \mathrm{~h}$; excitation time, $0.1 \mathrm{~s}$.

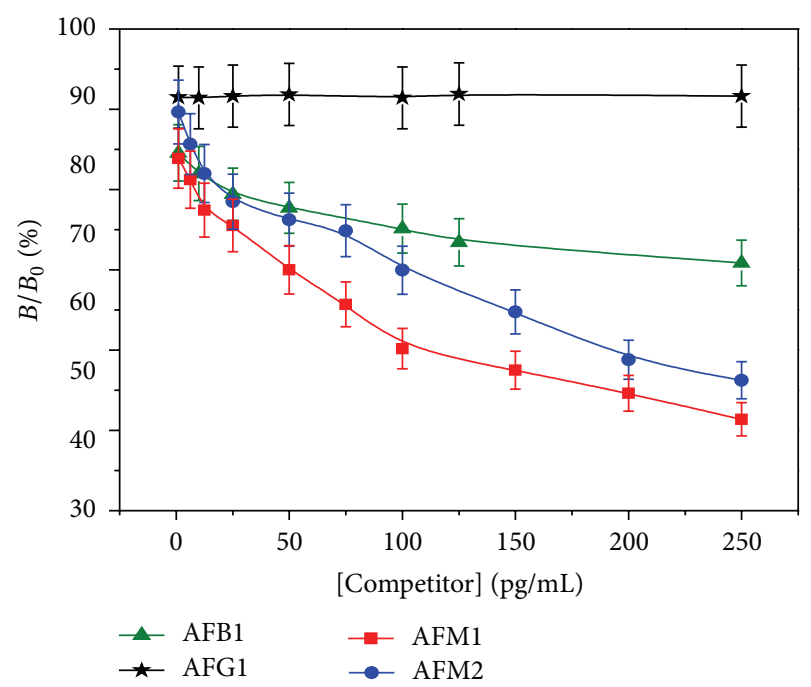

FIGURE 6: Fluorimetric analysis of aflatoxins at different concentrations carried out using 1:16000 $1^{\circ} \mathrm{mAb}$ in $\mathrm{CB}$ as capture antibody, FITC labeled $2^{\circ} \mathrm{Ab}$ used at 1:64000 dilution; incubation time was $2 \mathrm{~h}$, excitation time $0.1 \mathrm{~s}$.

obtained from calibrations and were used to compute the CR [12] using the formula

$$
\mathrm{CR}(\%)=\frac{\mathrm{IC}_{50} \text { value of standard analyte }}{\mathrm{IC}_{50} \text { value of cross reacting analyte }} \times 100 .
$$

To evaluate the sensitivity of the ELISA, the $\mathrm{IC}_{50}$ was obtained from the standard curves. The specificity of the ELISA was evaluated by determining the CR with structurally 
related aflatoxins. The mAb of AFM1 was highly specific to AFM1 and showed partial recognition towards its structural analogues AFM2 and AFB1. Figure 6 shows different aflatoxins specific recognition towards the mAb of AFM1 where concentrations of competitor were plotted against $B / B_{0}(\%)$, where $B_{0}$ is the maximum signal obtained in absence of analyte and $B$ is the signal obtained in presence of analyte concentration. Table 3 summarizes the $B / B_{0} \%$ of different aflatoxins.

The $\mathrm{IC}_{50}$ values of AFM1 and AFM2 were obtained, but for AFB1 and AFG1, $\mathrm{IC}_{50}$ could not be obtained as its $\mathrm{CR}$ with AFM1 mAb was not established. As indicated in Table 3, the mAb of AFM1 showed $23.2 \%$ CR with AFB1, approximately $50 \%$ with AFM2 and showed negligible (<1\%) CR with AFG1. The standard curve of AFM1 was used as reference in the ELISA as indicated in Figure 6.

3.5. Real Sample Analysis. The real sample analysis for two milk samples was carried out using mAb against AFM1 as receptors. The concentrations of AFM1, AFM2, AFB1, and AFG1 were determined in the two milk samples using $\mathrm{CR}$ approach coupled with standard addition method. The wells were coated by mAb of AFM1 and incubated. Then washing was done with PBS followed by blocking by BSA. In four different rows, the CRM-BD282 zero level AFM1 milk samples were spiked with $50 \mathrm{pg} / \mathrm{mL}$ of AFM1, AFB1, AFG1 and AFM2, respectively. Then milk samples 1 and 2 were added to the wells followed by FITC conjugated Ab. After incubation of about $2 \mathrm{~h}$ and washing with PBS, they were analyzed by multiplate reader. All experiments were made in triplicate. The recovery data are given in Table 4. The precision was determined by calculating the relative standard deviation (R.S.D.\%) for the replicate measurements. The R.S.D.\% and R.E.\% were calculated by the following formulae:

$$
\begin{aligned}
& \text { R.E. (relative error) } \% \\
& =\frac{\text { measured value }- \text { true value }}{\text { true value }} \times 100 ; n=3,
\end{aligned}
$$

R.S.D. (relative standard deviation) \%

$$
=\frac{\text { standard deviation }}{\text { mean }} \times 100 ; \quad n=3 \text {. }
$$

Results, as listed in Table 4, showed an acceptable recovery in the range of $90 \% \sim 101 \%$, and R.S.D. was from $0 \%$ to $8 \%$. It was noted that the CRM milk samples spiked with $50 \mathrm{pg} / \mathrm{mL}$ of AFM1 showed 100\% recovery. In S1, higher recovery was obtained as compared to S2. In case of AFM2, the recovery was found to be $91 \%$. Here also, S1 showed higher recovery than S2. For AFB1, the recovery was found to be $81 \%$, and when tested for S1 and S2, it showed $100.8 \%$ and 93.6\%, respectively. Although in S1 analysis for AFB1, >100\% recovery was obtained, the concentration $(400 \mathrm{pg} / \mathrm{mL})$ was much below the recommended level $(2 \mu \mathrm{g} / \mathrm{L})$. For AFG1 analysis, the recovery was $100.4 \%$. In this case, the recovery for S1 and S2 was obtained as $92.6 \%$ and $93.6 \%$, respectively.
TABLE 3: Summary of $B / B_{0} \%$ of various aflatoxins using standard curve of AFM1.

\begin{tabular}{lcccc}
\hline $\begin{array}{l}\text { [AFM1] from standard } \\
\text { curve }(\mathrm{pg} / \mathrm{mL})\end{array}$ & AFM1 & AFM2 & AFB1 & AFG1 \\
\hline 50 & 61 & 68 & 74 & 94 \\
100 & 52 & 62 & 71 & 92 \\
150 & 48 & 57 & N.R. & N.R. \\
200 & 45 & 50 & N.R. & N.R. \\
\hline
\end{tabular}

N.R.: not recorded.

3.6. Mixture Analysis. The CR studies were further carried out using mixture analysis. The mixture analysis was done by adding 50 and $25 \mathrm{pg} / \mathrm{mL}$ of AFM2 and AFB1 (individually) in varying amount of AFM1 in the range $1-100 \mathrm{pg} / \mathrm{mL}$ as shown in Figures 7(a) and 7(b).

It was observed that, at $12.5 \mathrm{pg} / \mathrm{mL}$ of AFM1, the AFM1 + AFM2 $(25 \mathrm{pg} / \mathrm{mL})$ mixture showed $4 \%$ and the AFM1 + AFM2 (50 pg/mL) mixture showed $10 \%$ lesser signal intensity than that of only AFM1. Similarly at $25 \mathrm{pg} / \mathrm{mL}$ of [AFM1], the mixture of both AFM1 + AFM2 (25 and $50 \mathrm{pg} / \mathrm{mL}$ ) showed $2 \%$ and $4 \%$ decreases in signal intensity, respectively, as compared to only [AFM1]. At the EU cutoff limit or $50 \mathrm{pg} / \mathrm{mL}$, there was no significant variation observed. Only $1.5 \%$ of decrease in signal intensity was obtained for AFM1 + AFM2 $(25 \mathrm{pg} / \mathrm{mL})$ mixture. But when analyzed for AFM1 + AFM2 (50 pg/mL) mixture, it showed $4 \%$ lesser signal when compared to only AFM1. At higher concentration of AFM1 (100 pg/mL), the AFM1 + AFM2 (25 pg/mL) showed $4 \%$ and the AFM1 + AFM2 (50 pg/mL) showed 5\% lesser signal intensity when compared to that of only AFM1. This mixture analysis postulates an account of some relation between CR and signal suppression. AFM2 showed almost 50\% CR with AFM1, and its presence as cocontaminant in the mixture resulted in small variation of 1.5 to $4 \%$ decrease at lower concentration $(25 \mathrm{pg} / \mathrm{mL})$, whereas at $50 \mathrm{pg} / \mathrm{mL}$, the signal suppression was observed in the range of 4 to $10 \%$ variation.

The mixture analysis was also carried out for AFB1 and AFM1 using anti-AFM1 antibody as shown in Figure 7(b). The standard calibration curve for AFM1 was plotted against mixture of AFM1 and AFB1 $(25,50 \mathrm{pg} / \mathrm{mL})$. In this case, further decline in signal intensities was observed. At $12.5 \mathrm{pg} / \mathrm{mL}$ of [AFM1], [AFB1] for 50 and $25 \mathrm{pg} / \mathrm{mL}$ showed $7.5 \%$ and $11.5 \%$ decrease in signal, respectively. For 25 and $50 \mathrm{pg} / \mathrm{mL}$ of [AFM1], the AFM1 + AFB1 (25 pg/mL) mixture showed the same decrease in signal of about $8 \%$, but for AFM1 + AFB1 $(50 \mathrm{pg} / \mathrm{mL})$ mixture it was $11 \%$ and $9.5 \%$, respectively. At higher concentration of AFM1 $(100 \mathrm{pg} / \mathrm{mL})$, the AFM1 + AFB1 $(25 \mathrm{pg} / \mathrm{mL})$ and AFM1 + AFB1 $(50 \mathrm{pg} / \mathrm{mL})$ mixtures showed 9 and $9.5 \%$ lesser intensities, respectively. The curve representing the mixture of [AFM1] with $100 \mathrm{pg} / \mathrm{mL}$ [AFB1] showed 12 and $10 \%$ less signal intensity of 25 and $50 \mathrm{pg} / \mathrm{mL}$, respectively, when compared to only [AFM1]. In all the mixtures of AFB1, the signal suppression was observed in a higher order of 7.5 to $11.5 \%$ variation when compared to the mixture analysis of AFM2. This difference has occurred for the reason of difference in CR of AFB1 with AFM1 
TABLE 4: Recovery studies of real milk sample fortified with different aflatoxins.

\begin{tabular}{|c|c|c|c|c|c|c|}
\hline Milk samples & Aflatoxin type & Added $(\mathrm{pg} / \mathrm{mL})$ & Found (pg/mL) & R.S.D.\% & R.E.\% & Recovery\% \\
\hline CRM-BD282 & AFM1 & 50 & 50 & 0 & 0 & 100 \\
\hline CRM-BD282 + S1 ${ }^{*}$ & AFM1 & 50 & 48.6 & $47 \pm 8$ & -2.8 & 97.2 \\
\hline CRM-BD $282+\mathrm{S}^{*}$ & AFM1 & 50 & 46 & $46.2 \pm 1.08$ & -8 & 92 \\
\hline CRM-BD282 & AFM2 & 50 & 45.5 & $45 \pm 0.55$ & -9 & 91 \\
\hline CRM-BD282 + S1 ${ }^{*}$ & AFM2 & 50 & 44.8 & $44.8 \pm 4.44$ & -10.4 & 89.6 \\
\hline CRM-BD $282+\mathrm{S}^{*}$ & AFM2 & 50 & 40.2 & $41 \pm 3.75$ & -19.6 & 80.4 \\
\hline CRM-BD282 & AFB1 & 50 & 40.5 & $40 \pm 5$ & -19 & 81 \\
\hline CRM-BD282 + S1 ${ }^{*}$ & AFB1 & 50 & 50.4 & $50.2 \pm 4.96$ & 0.8 & 100.8 \\
\hline CRM-BD282 + S2* & AFB1 & 50 & 46.8 & $46 \pm 4.34$ & -6.4 & 93.6 \\
\hline CRM-BD282 & AFG1 & 50 & 50.2 & $50 \pm 3.2$ & 0.4 & 100.4 \\
\hline CRM-BD282 + S1 ${ }^{*}$ & AFG1 & 50 & 46.3 & $46 \pm 1.76$ & -7.4 & 92.6 \\
\hline CRM-BD282 + S2* & AFG1 & 50 & 46.8 & $46 \pm 4.34$ & -6.4 & 93.6 \\
\hline
\end{tabular}

$\mathrm{S1}^{*}, \mathrm{~S}^{*}$ : real milk samples.

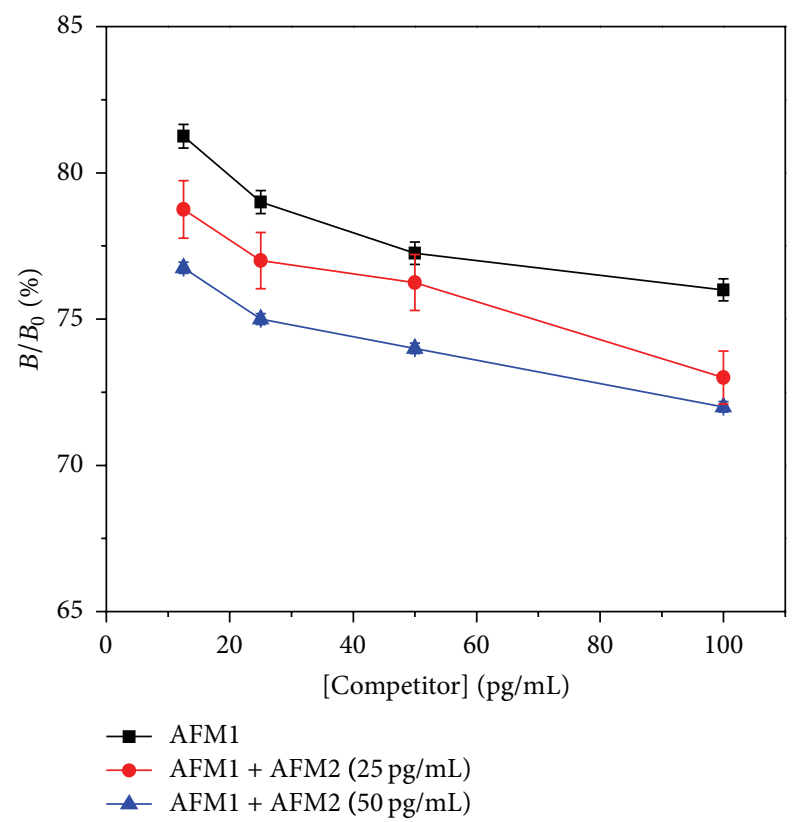

(a)

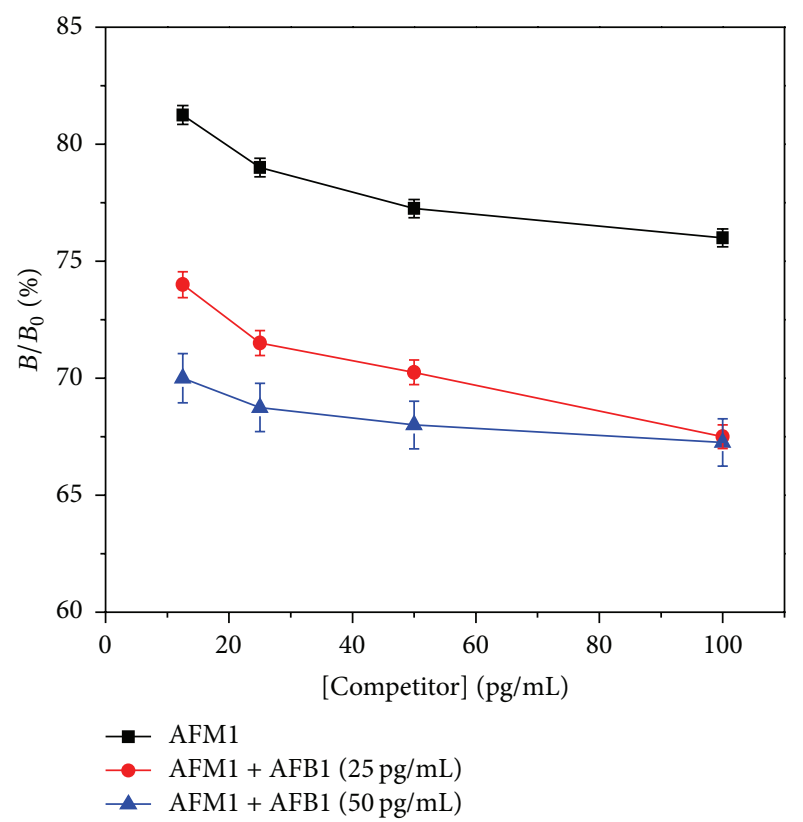

(b)

FIgURE 7: Mixture analysis by fluorimetric immunoassay: (a) AFM1 and AFM2 and (b) AFM1 and AFB1.

(23\%) which differs from 50\% CR of AFM2 with AFM1. This mixture analysis can play significant role in detecting and differentiating the presence of different aflatoxins which exist as cocontaminants found in the food commodities. Based on their CR properties, AFM1, AFM2, and AFB1 can be detected and quantified if found mixed in food samples.

\section{Conclusions}

This work illustrates a simple and sensitive fluorimetric multianalyte microwell plate based immunoassay for aflatoxins. Ultrasensitive analysis of AFM1 was successfully carried out by the developed technique with LOD as low as $1 \mathrm{pg} / \mathrm{mL}$. The presented protocol has been improved by eliminating one step in the immunoassay. ELISA for multianalysis of different aflatoxins was investigated in PBS, certified reference material for AFM1 and in real samples by fluorimetric technique in the microwell plate in presence of various types of competing analytes. Structurally analogous aflatoxins were analyzed using the CR concept. From the assay, it was observed that AFM2 showed the highest CR as compared with AFB1. AFG1 was least recognized by the anti-AFM1 antibodies. The multianalysis of different aflatoxins was also verified by the mixture analysis of AFM1 with AFB1 and AFM2. Assay on microwell plate allowed testing of highly toxic aflatoxins done with low sample volume and with easy handling. Besides the sensitivity and minimal reagent consumption, such multianalysis would lead to simultaneous screening of multiple analytes of aflatoxins. 


\section{Acknowledgments}

This work is funded by National Agriculture Innovation Project (NAIP) no. C4/C10125, ICAR, and The World Bank. Lizy Kanungo acknowledges NAIP for the Award of Research Associate Fellowship.

\section{References}

[1] S. Henry, T. Whitaker, I. Rabbani et al., Report 1012, Aflatoxin M1 (WHO Additives, series 47) Joint Expert Committee on Food Additives (JECFA), 2001.

[2] J. H. Williams, T. D. Phillips, P. E. Jolly, J. K. Stiles, C. M. Jolly, and D. Aggarwal, "Human aflatoxicosis in developing countries: a review of toxicology, exposure, potential health consequences, and interventions," American Journal of Clinical Nutrition, vol. 80, no. 5, pp. 1106-1122, 2004.

[3] M. J. Sweeney and A. D. W. Dobson, "Mycotoxin production by Aspergillus, Fusarium and Penicillium species," International Journal of Food Microbiology, vol. 43, no. 3, pp. 141-158, 1998.

[4] J. Stroka, R. V. Otterdijk, and E. Anklam, "Immunoaffinity column clean-up prior to thin-layer chromatography for the determination of aflatoxins in various food matrices," Journal of Chromatography A, vol. 904, no. 2, pp. 251-256, 2000.

[5] C. Brera, F. Debegnach, B. De Santis et al., "Simultaneous determination of aflatoxins and ochratoxin A in baby foods and paprika by HPLC with fluorescence detection: a singlelaboratory validation study," Talanta, vol. 83, no. 5, pp. 14421446, 2011.

[6] Y. Tan, X. Chu, G. Shen, and R. Yu, "A signal-amplified electrochemical immunosensor for aflatoxin B1 determination in rice," Analytical Biochemistry, vol. 387, no. 1, pp. 82-86, 2009.

[7] A. A. Fallah, T. Jafari, A. Fallah, and M. Rahnama, "Determination of aflatoxin M1 levels in Iranian white and cream cheese," Food and Chemical Toxicology, vol. 47, no. 8, pp. 1872-1875, 2009.

[8] B. van der Gaag, S. Spath, H. Dietrich et al., "Biosensors and multiple mycotoxin analysis," Food Control, vol. 14, no. 4, pp. 251-254, 2003.

[9] M. W. Trucksess, M. A. Dombrink-Kurtzman, V. H. Tournas, and K. D. White, "Occurrence of aflatoxins and fumonisins in Incaparina from Guatemala," Food Additives and Contaminants, vol. 19, no. 7, pp. 671-675, 2002.

[10] F. Ma, R. Chen, P. Li, Q. Zhang, W. Zhang, and X. Hu, "Preparation of an immunoaffinity column with Amino-Silica gel microparticles and its application in sample cleanup for aflatoxin detection in agri-products," Molecules, vol. 18, pp. 22222235, 2013.

[11] Y. Wang, H. Wang, P. Li et al., "Phage-displayed peptide that mimics aflatoxins and its application in immunoassay," Journal of Agricultural and Food Chemistry, vol. 61, pp. 2426-2433, 2013.

[12] S. Bhand, I. Surugiu, A. Dzgoev, K. Ramanathan, P. V. Sundaram, and B. Danielsson, "Immuno-arrays for multianalyte analysis of chlorotriazines," Talanta, vol. 65, no. 2, pp. 331-336, 2005.

[13] S. J. Daly, G. J. Keating, P. P. Dillon et al., "Development of surface plasmon resonance-based immunoassay for aflatoxin B1," Journal of Agricultural and Food Chemistry, vol. 48, no. 11, pp. 5097-5104, 2000.

[14] L. Fang, H. Chen, X. Ying, and J. Lin, "Micro-plate chemiluminescence enzyme immunoassay for aflatoxin B1 in agricultural products," Talanta, vol. 84, no. 1, pp. 216-222, 2011.
[15] Y. Wang, J. Dostálek, and W. Knoll, "Long range surface plasmon-enhanced fluorescence spectroscopy for the detection of aflatoxin M1 in milk," Biosensors and Bioelectronics, vol. 24, no. 7, pp. 2264-2267, 2009.

[16] A. Vig, A. Radoi, X. Muñoz-Berbel, G. Gyemant, and J. Marty, "Impedimetric aflatoxin M1 immunosensor based on colloidal gold and silver electrodeposition," Sensors and Actuators B, vol. 138, no. 1, pp. 214-220, 2009.

[17] E. Dinçkaya, Ö. Kinik, M. K. Sezgintürk, Ç. Altuĝ, and A. Akkoca, "Development of an impedimetric aflatoxin M1 biosensor based on a DNA probe and gold nanoparticles," Biosensors and Bioelectronics, vol. 26, no. 9, pp. 3806-3811, 2011.

[18] E. Larou, I. Yiakoumettis, G. Kaltsas, A. Petropoulos, P. Skandamis, and S. Kintzios, "High throughput cellular biosensor for the ultra-sensitive, ultra-rapid detection of aflatoxin M1," Food Control, vol. 29, pp. 208-212, 2013.

[19] A. Radoi, M. Targa, B. Prieto-Simon, and J.-L. Marty, "EnzymeLinked Immunosorbent Assay (ELISA) based on superparamagnetic nanoparticles for aflatoxin M1 detection," Talanta, vol. 77, no. 1, pp. 138-143, 2008.

[20] L. Anfossi, M. Calderara, C. Baggiani, C. Giovannoli, E. Arletti, and G. Giraudi, "Development and application of solvent-free extraction for the detection of aflatoxin M1 in dairy products by enzyme immunoassay," Journal of Agricultural and Food Chemistry, vol. 56, no. 6, pp. 1852-1857, 2008.

[21] K. Thirumala-Devi, M. A. Mayo, A. J. Hall et al., "Development and application of an indirect competitive enzymelinked immunoassay for aflatoxin $\mathrm{M} 1$ in milk and milk-based confectionery," Journal of Agricultural and Food Chemistry, vol. 50, no. 4, pp. 933-937, 2002.

[22] M. Badea, L. Micheli, M. C. Messia et al., "Aflatoxin M1 determination in raw milk using a flow-injection immunoassay system," Analytica Chimica Acta, vol. 520, no. 1-2, pp. 141-148, 2004.

[23] S. Rastogi, P. D. Dwivedi, S. K. Khanna, and M. Das, "Detection of Aflatoxin M1 contamination in milk and infant milk products from Indian markets by ELISA," Food Control, vol. 15, no. 4, pp. 287-290, 2004.

[24] S. C. Pei, Y. Y. Zhang, S. A. Eremin, and W. J. Lee, "Detection of aflatoxin M1 in milk products from China by ELISA using monoclonal antibodies," Food Control, vol. 20, no. 12, pp. 10801085, 2009.

[25] C. O. Parker, Y. H. Lanyon, M. Manning, D. W. M. Arrigan, and I. E. Tothill, "Electrochemical immunochip sensor for aflatoxin M1 detection," Analytical Chemistry, vol. 81, no. 13, pp. 52915298, 2009.

[26] M. Cuccioloni, M. Mozzicafreddo, S. Barocci et al., "Biosensorbased screening method for the detection of aflatoxins B1-G1," Analytical Chemistry, vol. 80, no. 23, pp. 9250-9256, 2008.

[27] L. Kanungo, S. Pal, and S. Bhand, "Miniaturised hybrid immunoassay for high sensitivity analysis of aflatoxin M1 in milk," Biosensors and Bioelectronics, vol. 26, no. 5, pp. 2601-2606, 2011.

[28] G. Bacher, S. Pal, L. Kanungo, and S. Bhand, "A label-free silver wire based impedimetric immunosensor for detection of aflatoxin M1 in milk," Sensors \& Actuators B, vol. 168, pp. 223230, 2012. 

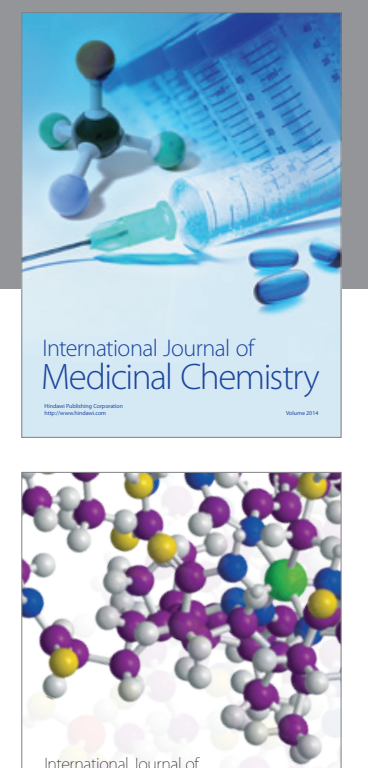

\section{Carbohydrate} Chemistry

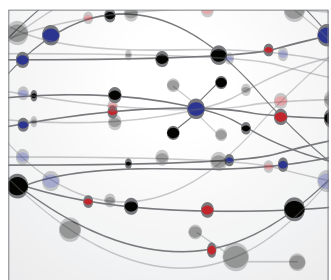

The Scientific World Journal
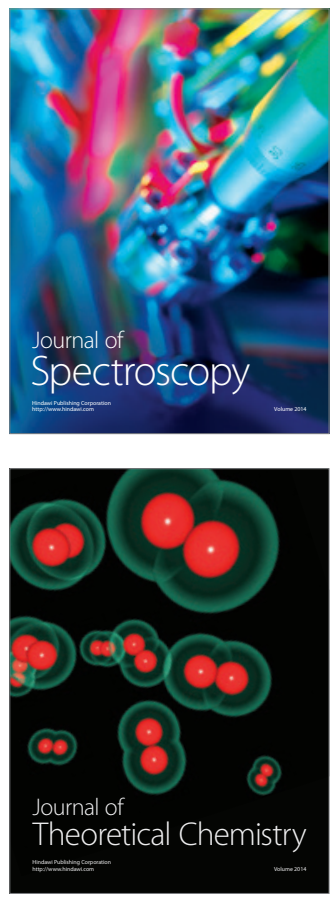
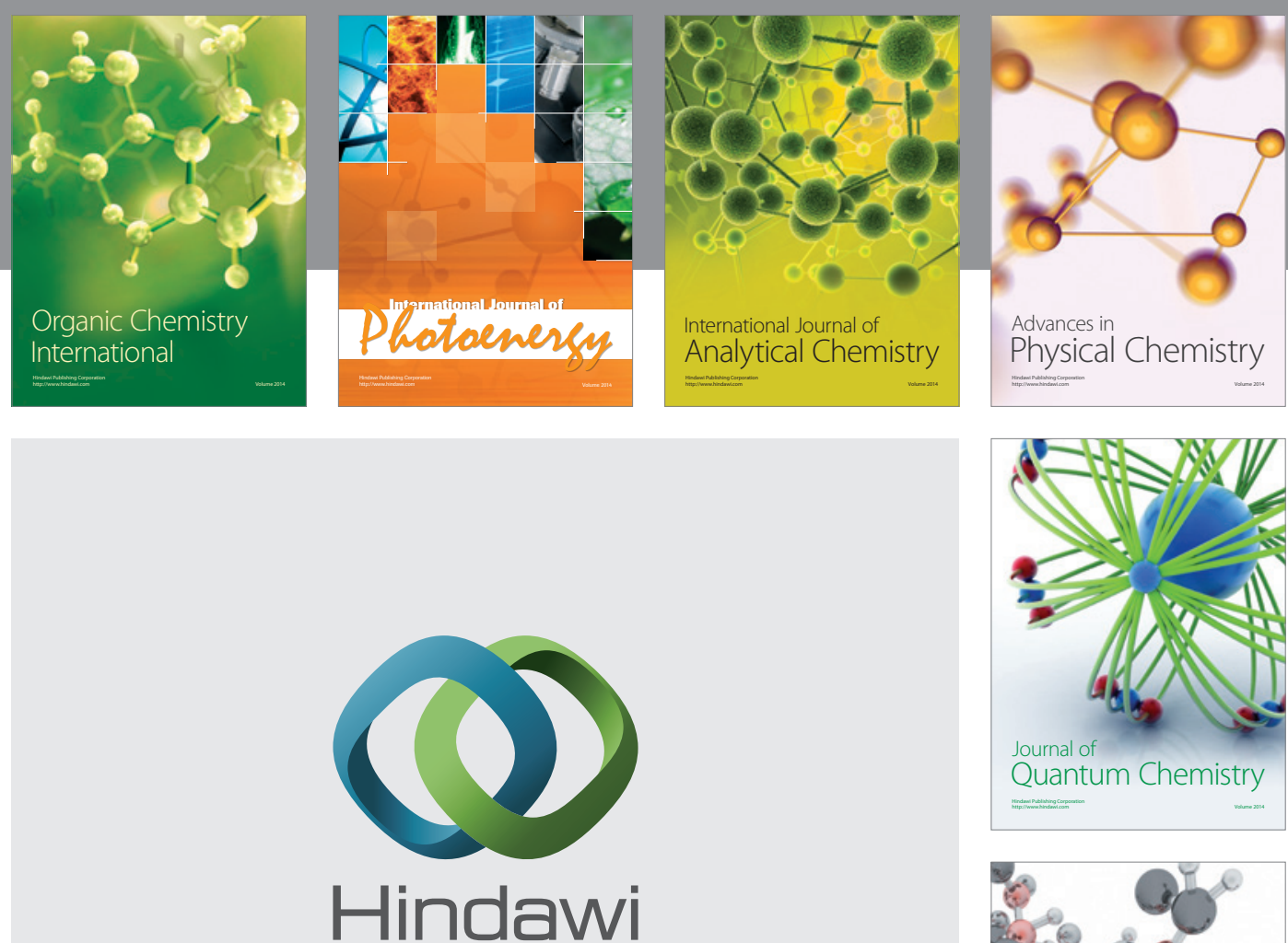

Submit your manuscripts at

http://www.hindawi.com

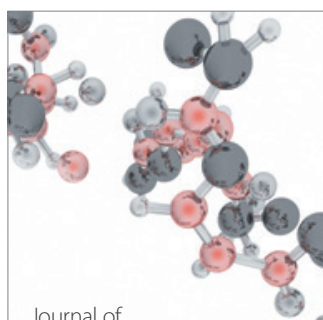

Analytical Methods

in Chemistry

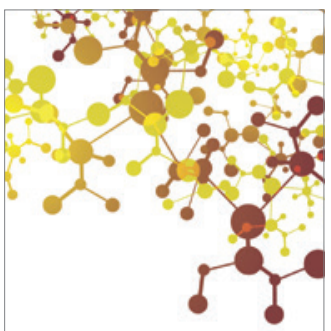

Journal of

Applied Chemistry

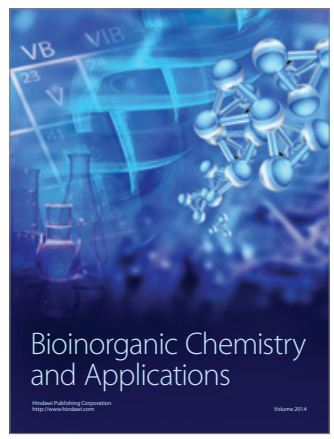

Inorganic Chemistry
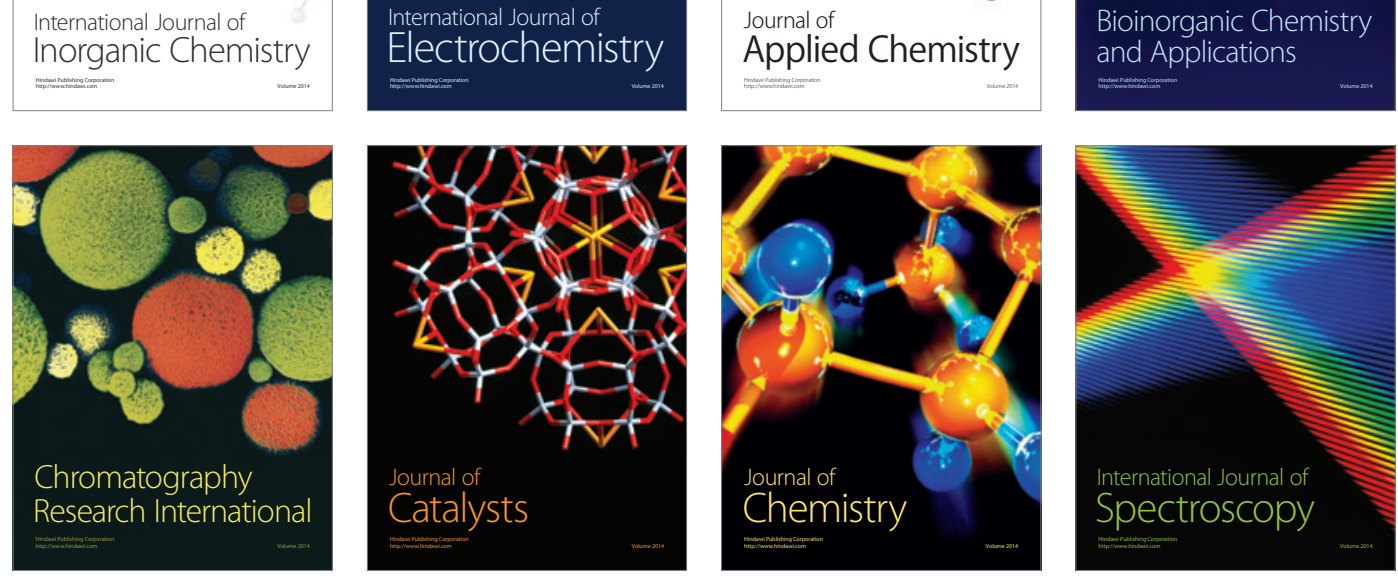